\title{
Pemberian Larutan Hara untuk Budidaya Tanaman Akar Wangi (Vetiveria zizanioides (L.) Nash) Menggunakan Teknologi Hidroponik Sistem Terapung (THST)
}

\author{
Nutrient Solution of Vetiver (Vetiveria zizanioides (L.) Nash) Cultivation Using \\ Hydrophonic Floating System Technology (HFST)
}

\author{
Siti Aisyah Rohmatus Sa'adah ${ }^{1}$ dan Slamet Susanto ${ }^{1 *}$
}

Diterima 6 April 2015 / Disetujui 22 Juni 2015

\begin{abstract}
The objective of this experiment was to determine the effect of concentration of nutrient solution on growth and yield of vetiver (Vetiveria zizanioides (L.) Nash) Verina 2 variety using Hydroponic Floating System Technology (HFST). This experiment was conducted in the greenhouse of Cikabayan Bawah, Experimental Farm IPB, with elevation of $240 \mathrm{~m}$ above sea level (asl) from December 2013 until February 2014. The experiment was based on a randomized complete block design which consisted of two experiments: (1) a plant without root cutting (3 replicates), (2) plants with root cutting (6 replicates), with one factor and three-levels: 200, 400, and 800 nutrient solution concentrations. The results showed that the concentration of the nutrient solution had significant effect on plant height, number of tillers, number of new saplings, shoot dry weight in plants that have not done cutting the roots, and root fresh weight in plants that have been done cutting the roots. Treatment of nutrient solution concentration of 200 ppm resulted in poor growth plants. Vetiver plants grown with the provision of nutrient solution concentration between 400 to 800 ppm acquired a better canopy growth and root development, therefore HFST could be applied to the cultivation of vitiver on the concentration of the nutrient solution to produce a better canopy growth and root development.
\end{abstract}

Key words: floating system, hydroponic, nutrient solution, vetiver

\begin{abstract}
ABSTRAK
Penelitian ini bertujuan untuk mengetahui pengaruh konsentrasi larutan hara terhadap pertumbuhan dan hasil akar wangi (Vetiveria zizanioides (L.) Nash) varietas Verina 2 dengan menggunakan Teknologi Hidroponik Sistem Terapung (THST). Penelitian ini merupakan penelitian lanjutan dari penelitian sebelumnya dan dilakukan di rumah kaca Kebun Penelitian Cikabayan Bawah IPB, dengan elevasi $240 \mathrm{~m}$ di atas permukaan laut (dpl) mulai dari bulan Desember 2013 hingga bulan Februari 2014. Penelitian disusun berdasarkan rancangan kelompok lengkap teracak (RKLT) yang terdiri atas dua percobaan: (1) tanaman tanpa pemotongan akar (3 ulangan), (2) tanaman dengan pemotongan akar (6 ulangan), dengan satu faktor dan tiga taraf: konsentrasi larutan hara 200, 400, dan 800 ppm. Hasil penelitian menunjukkan bahwa konsentrasi larutan hara berpengaruh nyata pada tinggi tanaman, jumlah anakan, jumlah anakan baru, dan bobot kering tajuk pada tanaman tanpa pemotongan akar, serta berpengaruh nyata terhadap bobot basah akar pada tanaman dengan pemotongan akar. Perlakuan konsentrasi larutan hara 200 ppm menghasilkan pertumbuhan dan perkembangan tanaman yang tidak baik. Tanaman akar wangi yang ditanam dengan pemberian konsentrasi larutan hara antara 400 sampai 800 ppm mempunyai pertumbuhan tajuk dan perkembangan akar tanaman yang lebih baik, oleh karena itu THST dapat diterapkan untuk budi daya akar wangi pada konsentrasi larutan hara tersebut sehingga dapat menghasilkan pertumbuhan tajuk dan perakaran yang baik.
\end{abstract}

Kata kunci: sistem terapung, hidroponik, larutan hara, akar wangi

${ }^{1}$ Departemen Agronomi dan Hortikultura, Fakultas Pertanian, Institut Pertanian Bogor

(Bogor Agricultural University), Jl. Meranti, Kampus IPB Darmaga, Bogor 16680, Indonesia

Telp.\&Faks. 62-251-8629353. *Email korespondensi: slmtsanto@gmail.com 


\section{PENDAHULUAN}

Tanaman akar wangi (Vetiveria zizanioides (L.) Nash) atau biasa disebut vetiver merupakan anggota famili Gramineae penghasil minyak atsiri penting di dunia. Kebutuhan minyak akar wangi dunia mencapai 300 ton tiap tahun. Saat ini Indonesia hanya mampu memenuhi sekitar 28\% saja dari kebutuhan minyak vetiver dunia (Mulyati et al., 2009). Rendemen minyak vetiver yang sangat rendah yaitu 1.5-2\% bobot kering, semakin menghambat peningkatan ekspor minyak vetiver (Sani, 2011). Mutu minyak akar wangi yang dihasilkan oleh petani Indonesia yang belum standar menyebabkan harga minyak vetiver yang sangat fluktuatif (Kardinan, 2005).

Perbaikan teknik budidaya vetiver dan kegiatan pemanenan merupakan tahap penting yang menentukan hasil minyak vetiver berkualitas tinggi. Kehilangan hasil pada proses pasca panen primer (pencucian dan pengeringan) dapat mencapai $65 \%$. Untuk menanggulangi kendala tersebut diperlukan satu teknologi budi daya yang tepat guna, salah satu teknologi budi daya yang dapat digunakan adalah teknologi hidroponik sistem terapung. Teknologi yang lebih maju ini penting untuk diterapkan guna meningkatkan produktivitas dan kualitas dari produksi tanaman vetiver (Mulyono et al., 2012).

Aplikasi teknologi hidroponik pada tanaman akar wangi diharapkan dapat menjadi salah satu solusi untuk mendapatkan akar wangi bermutu tinggi dengan input yang seminimal mungkin namun output yang maksimal dengan pemanenan yang mudah. Penelitian Ramadiani dan Susila (2014) menunjukkan bahwa hidroponik merupakan salah satu cara alternatif budidaya untuk peningkatan kualitas sayuran yang dihasilkan. Teknologi hidroponik merupakan kegiatan budi daya tanaman tanpa menggunakan media tanah, akan tetapi menggunakan media inert seperti gravel, pasir, peat, vermikulit, pumice atau sawdust, yang diberikan larutan hara yang mengandung semua elemen esensial yang diperlukan untuk pertumbuhan dan perkembangan normal tanaman (Resh, 1998).

Teknologi hidroponik sistem terapung (THST) adalah hasil modifikasi dari Deep Flowing System yang dikembangkan di Bagian Produksi Tanaman, Departemen Agronomi dan Hortikultura, Institut Pertanian Bogor
(Susila, 2013). Metode kultur air yaitu akar tanaman terendam dalam media cair yang merupakan larutan hara tanaman, sementara bagian atas tanaman ditunjang adanya lapisan medium inert tipis yang memungkinkan tanaman tumbuh tegak (Resh, 1998). Secara umum penelitian ini bertujuan memperoleh teknik budi daya menggunakan teknologi hidroponik sistem terapung untuk tanaman akar wangi sehingga dapat memudahkan proses panen dan menghasilkan biomassa akar dengan kandungan bahan aktif yang tinggi. Penelitian ini bertujuan untuk mengetahui pengaruh pemberian konsentrasi larutan hara, terhadap pertumbuhan tanaman akar wangi dengan menggunakan teknologi hidroponik sistem terapung (THST).

\section{METODE PENELITIAN}

Penelitian ini dilaksanakan di Rumah Kaca Kebun Percobaan Cikabayan Bawah, University Farm dan Laboratorium Spektofotometer-UV, Departemen Agronomi dan Hortikultura, Fakultas Pertanian IPB Dramaga Bogor. Penelitian ini merupakan penelitian lanjutan dari penelitian sebelumnya dan dilaksanakan pada bulan Desember 2013 hingga bulan Februari 2014.

Bahan yang diuji merupakan bibit akar wangi varietas Verina 2 yang diperoleh dari Balai Penelitian Tanaman Rempah dan Obat (Balittro) Cimanggu. Bahan tanam yang digunakan adalah bahan tanam dari penelitian sebelumnya yang berumur 10 bulan. Komposisi larutan hara stok A terdiri atas $\mathrm{Ca}\left(\mathrm{NO}_{3}\right)_{2}: 3510$ g, dan Fe-EDTA: 360 g, sedangkan komposisi larutan hara stok B terdiri atas $\left(\mathrm{NH}_{4}\right)_{2} \mathrm{SO}_{4}: 648 \mathrm{~g}, \mathrm{~K}_{2} \mathrm{HPO}_{4}: 1293$ g, $\mathrm{MgSO}_{4} .7 \mathrm{H}_{2} \mathrm{O}: 3325 \mathrm{~g}, \mathrm{MnSO}_{4} .3 \mathrm{H}_{2} \mathrm{O}: 36.6$ g, $\mathrm{CuSO}_{4} \cdot \mathrm{H}_{2} \mathrm{O}: 0.7 \mathrm{~g}, \mathrm{Na}_{2} \mathrm{~B}_{4} \mathrm{O}_{7} .10 \mathrm{H}_{2} \mathrm{O}: 32 \mathrm{~g}$, $\mathrm{ZnSO}_{4} \mathrm{H}_{2} \mathrm{O}: 7.9 \mathrm{~g}, \mathrm{H}_{3} \mathrm{BO}_{3}$ : $20.6 \mathrm{~g},\left(\mathrm{NH}_{4}\right)_{6}$ $\mathrm{Mo}_{7} \mathrm{O}_{2} \cdot 4 \mathrm{H}_{2} \mathrm{O}: 1.56 \mathrm{~g}$, dan $\mathrm{Na}_{2} \mathrm{MoO}_{4} \cdot 2 \mathrm{H}_{2} \mathrm{O}: 1.6 \mathrm{~g}$.

Alat yang digunakan meliputi bak tanam berukuran $55 \mathrm{~cm} \times 55 \mathrm{~cm} \times 65 \mathrm{~cm}$, panel floating dibuat dari kayu yang berukuran (panjang x lebar) $65 \mathrm{~cm} \times 65 \mathrm{~cm}$ dengan ketebalan $3 \mathrm{~cm}$ sehingga dapat diletakkan pada permukaan bak tanpa tenggelam, timbangan analitik, meteran, alat tulis, gunting pangkas, terpal, aerator, dan oven.

Penelitian sebelumnya telah menghasilkan tanaman yang belum dan sudah dipotong 
akarnya. Tanaman tersebut dirawat untuk dijadikan bahan tanam penelitian ini dan dijadikan sebagai bahan tanam Percobaan 1 dengan bahan tanam yang belum dipotong akarnya dan Percobaan 2 dengan bahan tanam yang sudah dipotong akarnya. Kegiatan pemeliharaan tanaman meliputi pengendalian hama dan penyakit, penambahan air, serta pemasangan terpal untuk menjaga kondisi bak agar tidak terjadi kebocoran. Pengurasan bak tanam dilakukan setiap satu bulan sekali dengan dilakukan penggantian larutan hara. Pemanenan tanaman vetiver dilakukan sesuai dengan waktu panen yang telah ditentukan yaitu pada saat tanaman mencapai umur 12 bulan.

Komponen pengamatan yang diamati setiap minggu, antara lain: jumlah anakan baik anakan besar maupun anakan yang baru muncul, tinggi tanaman $(\mathrm{cm})$ yang diukur dari pangkal tanaman sampai ujung daun tertinggi, jumlah daun yang sudah membuka sempurna, panjang akar $(\mathrm{cm})$ yang diukur dari pangkal akar sampai ujung akar, jumlah akar besar dengan diameter $>2 \mathrm{~mm}$, jumlah akar kecil dengan diameter $<2 \mathrm{~mm}$, jumlah akar yang baru muncul, dan suhu $\left({ }^{0} \mathrm{C}\right)$. Komponen pengamatan yang diamati pada saat 3 bulan sekali yaitu Krolofil daun yang diukur dengan alat Spektrophotometer-UV dan komponen yang diamati pada saat panen yaitu bobot akar basah $(\mathrm{g})$, bobot brangkasan basah $(\mathrm{g})$, serta bobot brangkasan kering ( $\mathrm{g}$ ).

Metode stressing dilakukan pada saat umur tanaman mencapai 10 bulan dan pada awal penelitian lanjutan berlangsung, dengan cara mengurangi volume air dari volume awal $150 \mathrm{~L}$ dengan cara diambil setengah dari volume awal pada Percobaan 1 sehingga menjadi setengah volume yang tersisa sebanyak $75 \mathrm{~L}$ itu akan digunakan dalam penelitian dengan ditambahkan konsentrasi larutan hara 200, 400, dan 800 ppm. Percobaan 2 juga dilakukan stressing air dari volume awal $150 \mathrm{~L}$ dengan cara diambil $1 / 4$ dari volume awal sehingga menjadi $3 / 4$ volume air yang tersisa sebanyak $112.5 \mathrm{~L}$ itu akan digunakan dalam penelitian dengan ditambahkan konsentrasi larutan hara 200, 400, dan 800 $\mathrm{ppm}$. Metode stressing ini dilakukan untuk mempercepat proses kematangan akar sehingga dapat menghasilkan rendemen minyak atsiri yang lebih baik.

Penelitian ini terdiri atas bahan tanaman yang belum dilakukan pemotongan akar (Percobaan 1), dan dari bahan tanaman yang sudah dilakukan pemotongan akar (Percobaan 2). Pemotongan akar dilakukan pada saat tanaman mencapai umur 10 bulan. Percobaan 1 (tanpa pemotongan akar) diulang sepuluh kali, sedangkan Percobaan 2 (dengan pemotongan akar) terdiri atas enam ulangan. Unit percobaan ialah satu polibag.

Data pengamatan yang diperoleh dianalisis dengan sidik ragam (uji F) pada taraf $\alpha=5 \%$. Jika terdapat pengaruh nyata dari perlakuan yang di uji berdasarkan uji F-hitung pada taraf $\alpha=5 \%$, maka dilakukan uji lanjut untuk melihat perbedaan antar perlakuan dengan Uji DMRT pada taraf $\alpha=5 \%$. Data diolah menggunakan software SAS (Gomez dan Gomez, 1995).

\section{HASIL DAN PEMBAHASAN}

\section{Kondisi Umum}

Suhu rata-rata harian selama penelitian berlangsung yaitu $31.3{ }^{\circ} \mathrm{C}$, dengan rata-rata suhu pada saat pagi hari $29.2{ }^{\circ} \mathrm{C}$, suhu pada saat siang hari $41.8{ }^{\circ} \mathrm{C}$, dan suhu pada saat sore hari $23.7{ }^{\circ} \mathrm{C}$. Intensitas radiasi matahari yang tertinggi yang diperoleh dari Badan Meteorologi Klimatologi dan Geofisika (BMKG) Stasiun Klimatologi Dramaga Bogor adalah pada 43 MSP yaitu sekitar $14.7 \mathrm{MJ} \mathrm{m}^{-2}$ dan terendah pada $45 \mathrm{MSP}$ yaitu $6.2 \mathrm{MJ} \mathrm{m}^{-2}$.

Pertumbuhan tanaman selama penelitian ini menunjukkan semakin melambatnya proses pertumbuhan tanaman, bagian yang mudah diketahui menurunnya pertumbuhan yaitu jumlah daun dan jumlah anakan tanaman. Hal ini disebabkan umur tanaman yang sudah memasuki fase penuaan atau senesen. Rosman et al. (2013) menyatakan bahwa menurunnya jumlah anakan dan jumlah daun ini disebabkan karena fase pertumbuhan tanaman yang mulai ke arah fase generatif dan lebih berpusat kepada proses pembentukan minyak. 


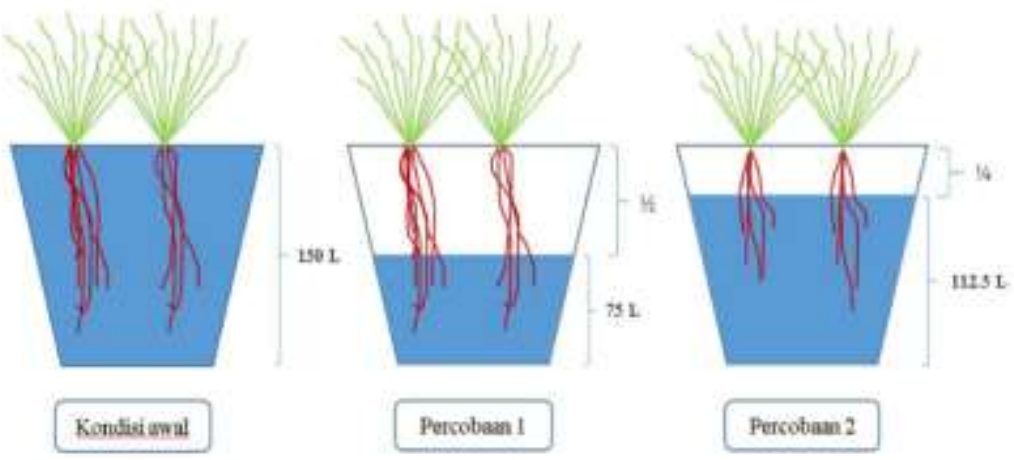

Gambar 1. Metode stressing pada masing-masing percobaan
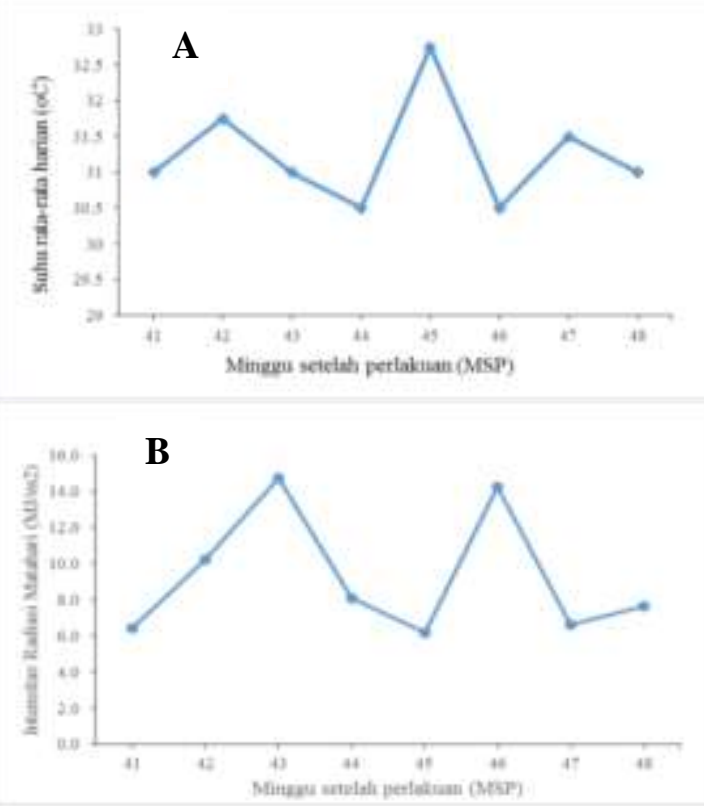

Gambar 2. Suhu rata-rata harian (A) dan intensitas radiasi matahari (B) selama penelitian

\section{Rekapitulasi Sidik Ragam}

Hasil rekapitulasi analisis sidik ragam pada Tabel 1 menunjukkan bahwa ringkasan hasil penelitian untuk seluruh peubah pengamatan karakter agronomi dan karakter fisiologi pada saat 48 minggu setelah tanam (MSP). Berdasarkan hasil rekapitulasi sidik ragam diketahui bahwa konsentrasi larutan hara menunjukkan pengaruh nyata terhadap tinggi tanaman, jumlah anakan, jumlah anakan baru, dan bobot kering tajuk pada Percobaan 1 dengan bahan tanam yang tanpa pemotongan akar. Konsentrasi larutan hara juga memberikan pengaruh nyata terhadap hasil jumlah anakan baru, bobot kering tajuk, dan bobot basah akar pada Percobaan 2 dengan bahan tanam yang dengan pemotongan akar. Konsentrasi larutan hara tidak menunjukkan adanya pengaruh nyata terhadap hasil yang diamati pada seluruh karakter fisiologi pada percobaan 2 dengan bahan tanam yang dengan pemotongan akar.

\section{Komponen Pertumbuhan Vegetatif Tanaman Vetiver}

Konsentrasi larutan hara memberikan pengaruh yang nyata terhadap tinggi tanaman, jumlah anakan, dan jumlah anakan baru tanaman akar wangi pada umur 48 MSP yang disajikan pada Tabel 2. Berdasarkan data yang diperoleh pada penelitian ini konsentrasi larutan hara memberikan pengaruh nyata terhadap tinggi tanaman akar wangi pada umur 48 MSP pada percobaan 1 dengan bahan tanam yang tanpa pemotongan akar. 
Tabel 1. Seluruh peubah pengamatan karakter agronomi dan karakter fisiologi tanaman akar wangi pada saat 48 MSP

\begin{tabular}{|c|c|c|c|c|}
\hline \multirow[t]{2}{*}{ Peubah yang Diamati } & \multicolumn{2}{|c|}{$\begin{array}{c}\text { Percobaan } 1 \\
\text { (Tanpa Pemotongan Akar) }\end{array}$} & \multicolumn{2}{|c|}{$\begin{array}{c}\text { Percobaan } 2 \\
\text { (Dengan Pemotongan Akar) }\end{array}$} \\
\hline & Uji-F & $\mathrm{KK}(\%)$ & Uji-F & $\mathrm{KK}(\%)$ \\
\hline \multicolumn{5}{|l|}{ Karakter Agronomi } \\
\hline Tinggi tanaman $(\mathrm{cm})$ & $*$ & 6.44 & $\operatorname{tn}$ & 15.16 \\
\hline Jumlah daun (helai) & tn & 23.12 & tn & $21.76^{\mathrm{tr}}$ \\
\hline Jumlah anakan (unit) & $*$ & 11.08 & tn & $20.14^{\text {tr }}$ \\
\hline Jumlah anakan baru (unit) & $*$ & 5.28 & $* *$ & $24.21^{\text {tr }}$ \\
\hline Bobot basah tajuk (g) & tn & 20.54 & tn & 20.02 \\
\hline Bobot kering tajuk (g) & $*$ & 17.11 & $*$ & 20.82 \\
\hline Panjang akar (cm) & tn & 8.93 & tn & 20.64 \\
\hline Jumlah akar besar (unit) & tn & $13.71^{\text {tr }}$ & tn & $23.94^{\text {tr }}$ \\
\hline Jumlah akar kecil (unit) & tn & $22.18^{\operatorname{tr}}$ & tn & $21.57^{\operatorname{tr}}$ \\
\hline Jumlah akar baru (unit) & tn & $29.67^{\text {tr }}$ & tn & $27.37^{\text {tr }}$ \\
\hline Bobot basah akar (g) & tn & 18.10 & * & 11.86 \\
\hline \multicolumn{5}{|l|}{ Karakter Fisiologi } \\
\hline Klorofil a (mg g $\left.{ }^{-1}\right)$ & - & - & tn & $16.22^{\text {tr }}$ \\
\hline Klorofil b ( $\left.\mathrm{mg} \mathrm{g}^{-1}\right)$ & - & - & tn & $11.46^{\text {tr }}$ \\
\hline Karoten $\left(\mathrm{mg} \mathrm{g}^{-1}\right)$ & - & - & tn & $8.99^{\text {tr }}$ \\
\hline Antosianin $\left(\mu \mathrm{mol} \mathrm{g}^{-1}\right)$ & - & - & tn & $7.19^{\text {tr }}$ \\
\hline Klorofil total ( $\mathrm{mg} \mathrm{g}^{-1}$ ) & - & - & tn & $16.90^{\operatorname{tr}}$ \\
\hline
\end{tabular}

Konsentrasi larutan hara $400 \mathrm{ppm}$ menunjukkan hasil nilai yang paling baik dibanding konsentrasi larutan hara 200 dan $800 \mathrm{ppm},(129.60 \mathrm{~cm}$ pada konsentrasi larutan hara $400 \mathrm{ppm}, 110.76 \mathrm{~cm}$ pada konsentrasi larutan hara $800 \mathrm{ppm}, 50.50 \mathrm{~cm}$ pada konsentrasi larutan hara $200 \mathrm{ppm})$ pada Percobaan 1. Konsentrasi larutan hara tidak memberikan pengaruh nyata tehadap tinggi tanaman akar wangi pada umur 48 MSP pada Percobaan 2 dengan bahan tanam dengan pemotongan akar.

Konsentrasi larutan hara $200 \mathrm{ppm}$ menunjukkan tinggi tanaman mencapai 108.18 $\mathrm{cm}$, konsentrasi larutan hara $400 \mathrm{ppm}$ tinggi tanamannya mencapai $102.54 \mathrm{~cm}$, dan konsentrasi larutan hara $800 \mathrm{ppm}$ tinggi tanamannya mencapai $110.95 \mathrm{~cm}$, tetapi pada Percobaan 2 ini konsentrasi larutan hara tidak memberikan pengaruh nyata terhadap tinggi tanaman yang dihasilkan.

Pada Percobaan 1 umur 48 MSP, tanaman memiliki jumlah daun rata-rata terendah yaitu 10.0 helai pada konsentrasi larutan hara 200 ppm, sedangkan pada Percobaan 2 tanaman memiliki jumlah daun terendah rata-rata yaitu 86.3 helai pada konsentrasi larutan hara 800 ppm. Berdasarkan data pada Tabel 2, konsentrasi larutan hara tidak memberikan pengaruh nyata terhadap pertumbuhan jumlah daun tanaman akar wangi pada umur 48 MSP baik pada Percobaan 1 dan Percobaan 2. Konsentrasi larutan hara $200 \mathrm{ppm}$ menghasilkan jumlah daun sebanyak 10.0 helai, konsentrasi larutan hara $400 \mathrm{ppm}$ menghasilkan jumlah daun sebnyak 221.7 helai, dan konsentrasi larutan hara 800 ppm menghasilkan jumlah daun sebanyak 169.0 helai pada Percobaan 1.

Pada Percobaan 2, konsentrasi larutan hara 200 ppm menghasilkan jumlah daun sebanyak 113.0 helai, konsentrasi larutan hara 400 ppm menghasilkan jumlah daun sebanyak 138.2 helai, dan konsentrasi larutan hara 800 ppm menghasilkan jumlah daun sebanyak 86.3 helai. Jumlah daun yang mengalami penurunan ini dikarenakan pertumbuhan tanaman sudah memasuki fase penuaan atau senesen, sehingga dapat menyebabkan daun menjadi layu dan mengering, dan juga karena stressing yang dilakukan pada masing-masing percobaan menjadikan akar tanaman menjadi tidak tercelup sebagian pada Percobaan 1 sehingga kemampuan penyerapan hara dari akar ke bagian tanaman yang lain menjadi terhambat 
dan dapat menyebabkan daun kekurangan unsur hara yang membuat daun menjadi mengering.

Konsentrasi larutan hara memberikan pengaruh nyata terhadap jumlah anakan yang dihasilkan pada Percobaan 1 (Tabel 4). Konsentrasi larutan hara 400 ppm menunjukkan hasil jumlah anakan yang paling banyak diantara konsentrasi yang lainnya sebanyak 53.3 unit, konsentrasi larutan hara $800 \mathrm{ppm}$ menghasilkan jumlah anakan sebanyak 41.0 unit, dan konsentrasi larutan hara 200 ppm menghasilkan jumlah anakan yang paling sedikit yaitu 4.0 unit dengan bahan tanam tanpa pemotongan akar (Percobaan 1). Konsentrasi larutan hara tidak menunjukkan adanya pengaruh yang nyata terhadap jumlah anakan tanaman akar wangi pada Percobaan 2 dengan bahan tanam yang dengan pemotongan akar.

\section{Pertumbuhan dan Produksi Akar Tanaman Vetiver}

Konsentrasi larutan hara tidak berpengaruh nyata terhadap panjang akar, jumlah akar besar, jumlah akar kecil, dan jumlah akar baru. Panjang akar tanaman Percobaan 1 dan Percobaan 2 pada konsentrasi larutan hara 800 ppm menunjukkan nilai rata-rata paling tinggi dibanding konsentrasi larutan hara 400 dan 200 ppm, sedangkan pada keseluruhan peubah pengamatan jumlah akar besar, jumlah akar kecil, dan jumlah akar baru hasil nilai yang paling baik pada konsentrasi larutan hara 400 ppm (Tabel 3).

Metode stressing menyebabkan akar hanya terendam sebagian sehingga konsentrasi larutan hara tidak memberikan pengaruh nyata terhadap jumlah akar baru karena adanya celah dari bagian pangkal tanaman dengan air sehingga akar menjadi lebih sedikit untuk tumbuh, karena tidak mampu menyerap hara dengan efektif. Produksi akar yang paling banyak adalah akar kecil (diameter $<2 \mathrm{~mm}$ ), antara tanaman tanpa dan dengan pemotongan akar, konsentrasi larutan hara juga tidak memberikan pengaruh nyata terhadap jumlah akar kecil baik dalam Percobaan 1 dengan bahan tanam yang belum dipotong akarnya maupun Percobaan 2 dengan bahan tanam yang sudah dipotong akarnya.

Rosihan et al. (2010) menyatakan bahwa konsentrasi hara yang paling efektif bagi pertumbuhan tanaman vetiver untuk merangsang pertumbuhan akarnya berkisar pada konsentrasi 400-500 ppm karena unsur hara makro akan bekerja merangsang pertumbuhan terutama unsur $\mathrm{K}$ akan merangsang pertumbuhan akar tanaman vetiver.

Jumlah akar besar pada tanaman Percobaan 1 rata-rata akar yang paling banyak yaitu pada konsentrasi larutan hara $400 \mathrm{ppm}$ yaitu 52.7 unit dan pada tanaman Percobaan 2 juga pada perlakuan konsentrasi larutan hara 400 ppm yaitu 19.8 unit. Pada konsentrasi larutan hara 200 ppm dari tanaman Percobaan 1 dan 2 juga memiliki jumlah akar besar ratarata lebih kecil berurut-urut 35.0 unit dan 16.5 unit (Tabel 3). Hal tersebut menunjukkan bahwa penambahan hara sangat diperlukan dalam budidaya akar wangi menggunakan THST karena jumlah akar besar dan akar kecil memiliki peranan penting dalam mengabsorpsi air dan hara yang dibutuhkan tanaman.

Tabel 2. Pengaruh konsentrasi larutan hara terhadap tinggi tanaman, jumlah daun, jumlah anakan, jumlah anakan baru, dan bobot basah tajuk pada 48 MSP

\begin{tabular}{|c|c|c|c|c|}
\hline Konsentrasi Larutan Hara & $\begin{array}{l}\text { Tinggi Tanaman } \\
(\mathrm{cm})\end{array}$ & $\begin{array}{c}\text { Jumlah Daun } \\
\text { (helai) }\end{array}$ & $\begin{array}{l}\text { Jumlah Anakan } \\
\text { (unit) }\end{array}$ & $\begin{array}{l}\text { Jumlah Anakan Baru } \\
\text { (unit) }\end{array}$ \\
\hline \multicolumn{5}{|c|}{ Percobaan 1 (Tanpa Pemotongan Akar) } \\
\hline $200 \mathrm{ppm}$ & $50.50 \mathrm{~b}$ & 10.0 & $4.0 \mathrm{~b}$ & $3.0 \mathrm{~b}$ \\
\hline 400 ppm & $129.60 \mathrm{a}$ & 221.7 & $53.3 \mathrm{a}$ & $25.0 \mathrm{a}$ \\
\hline $800 \mathrm{ppm}$ & $110.76 \mathrm{a}$ & 169.0 & $41.0 \mathrm{a}$ & $21.7 \mathrm{a}$ \\
\hline \multicolumn{5}{|c|}{ Percobaan 2 (Dengan Pemotongan Akar) } \\
\hline $200 \mathrm{ppm}$ & 108.18 & 113.0 & 24.5 & $6.5 \mathrm{~b}$ \\
\hline $400 \mathrm{ppm}$ & 102.53 & 138.2 & 35.3 & $19.5 \mathrm{a}$ \\
\hline $800 \mathrm{ppm}$ & 110.95 & 86.3 & 21.5 & $9.2 \mathrm{~b}$ \\
\hline
\end{tabular}

Keterangan: Angka-angka pada kolom yang sama yang diikuti oleh huruf yang sama tidak berbeda nyata pada taraf uji 5\% (uji selang berganda Duncan). 


\section{Kandungan Klorofil Tanaman Vetiver}

Konsentrasi larutan hara tidak memberikan pengaruh nyata terhadap kandungan klorofil, karoten, dan antosianin pada tanaman vetiver waktu 48 MSP. Kandungan klorofil yang diambil hanya sebagian sampel yang mewakili dari ketiga perlakuan pada tanaman Percobaan 2 (Tabel 4).

Tanaman dari Percobaan 1 sebagian sudah mati sehingga tidak dilakukan pengukuran. Kandungan klorofil dari tanaman Percobaan 2 pada daun tanaman vetiver menunjukkan nilai dari yang tertinggi sampai terendah secara berurutan yaitu klorofil a, klorofil b, karoten, dan antosianin pada konsentrasi larutan hara 400 ppm.

Kandungan klorofil yang paling rendah ditunjukkan pada perlakuan konsentrasi larutan hara 200 ppm, hal ini dapat menyebabkan rendahnya kandungan klorofil karena komposisi hara yang terkandung pada konsentrasi larutan hara tersebut sangat sedikit sehingga hara yang tersedia tidak dapat memenuhi kebutuhan tanaman dengan baik.

Tabel 3. Pengaruh konsentrasi larutan hara terhadap panjang akar, jumlah akar besar, jumlah akar kecil, dan jumlah akar baru muncul pada $48 \mathrm{MSP}$

\begin{tabular}{lcccc}
\hline $\begin{array}{l}\text { Konsentrasi } \\
\text { Larutan Hara }\end{array}$ & $\begin{array}{c}\text { Panjang Akar } \\
(\mathrm{cm})\end{array}$ & $\begin{array}{r}\text { Jumlah Akar Besar } \\
\text { (unit) }\end{array}$ & $\begin{array}{r}\text { Jumlah Akar Kecil } \\
\text { (unit) }\end{array}$ & $\begin{array}{c}\text { Jumlah Akar Baru } \\
\text { (unit) }\end{array}$ \\
\hline \multirow{2}{*}{$\begin{array}{c}\text { Percobaan 1 (Tanpa Pemotongan Akar) } \\
\text { ppm }\end{array}$} & 135.10 & 35.0 & 151.0 & 5.0 \\
$400 \mathrm{ppm}$ & 136.60 & 52.7 & 209.3 & 19.3 \\
$800 \mathrm{ppm}$ & 152.93 & 21.7 & 105.0 & 15.7 \\
\hline & \multicolumn{4}{c}{ Percobaan 2 (Dengan Pemotongan Akar) } \\
$200 \mathrm{ppm}$ & 81.43 & 16.5 & 151.4 & 12.2 \\
$400 \mathrm{ppm}$ & 85.68 & 19.8 & 97.0 & 13.0 \\
$800 \mathrm{ppm}$ & 89.48 & 18.0 & 118.2 & 11.2 \\
\hline
\end{tabular}

Keterangan: Angka-angka pada kolom yang sama yang diikuti oleh huruf yang sama tidak berbeda nyata pada taraf uji 5\% (uji selang berganda Duncan); akar besar (diameter $>2 \mathrm{~mm}$ ); akar kecil (diameter < $2 \mathrm{~mm}$ ); akar baru : akar yang masih berwarna putih.
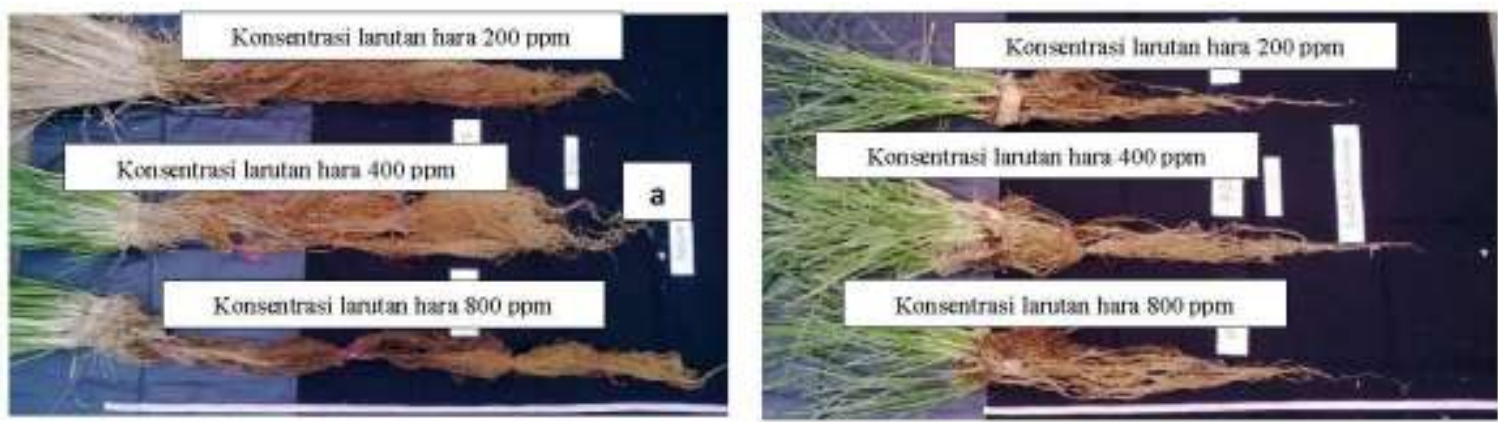

Gambar 3. Keragaman tanaman vetiver pada konsentrasi larutan hara yang berbeda pada 48 MSP, (a) tanaman belum dilakukan pemotongan akar (Percobaan 1) dan (b) tanaman sudah dilakukan pemotongan akar (Percobaan 2).

Tabel 4. Pengaruh konsentrasi hara terhadap kandungan klorofil tanaman vetiver pada 48 MSP

\begin{tabular}{lccccc}
\hline $\begin{array}{c}\text { Konsentrasi Larutan } \\
\text { Hara }\end{array}$ & $\begin{array}{c}\text { Klorofil a } \\
\left(\mathrm{mg} \mathrm{g}^{-1}\right)\end{array}$ & $\begin{array}{c}\text { Klorofil b } \\
\left(\mathrm{mg} \mathrm{g}^{-1}\right)\end{array}$ & $\begin{array}{c}\text { Karoten } \\
\left(\mathrm{mg} \mathrm{g}^{-1}\right)\end{array}$ & $\begin{array}{c}\text { Antosianin } \\
\left(\mu \mathrm{mol} \mathrm{g}^{-1}\right)\end{array}$ & $\begin{array}{c}\text { Klorofil Total } \\
\left(\mathrm{mg} \mathrm{g}^{-1}\right)\end{array}$ \\
\hline & \multicolumn{5}{c}{ Percobaan 2 } \\
(Dengan Pemotongan Akar $)$ \\
$200 \mathrm{ppm}$ & 1.50 & 0.54 & 0.36 & 0.24 & 2.04 \\
$400 \mathrm{ppm}$ & 2.75 & 0.94 & 0.58 & 0.30 & 3.69 \\
$800 \mathrm{ppm}$ & 2.34 & 0.80 & 0.48 & 0.26 & 3.14 \\
\hline
\end{tabular}

Keterangan: Angka-angka pada kolom yang sama yang diikuti oleh huruf yang sama tidak berbeda nyata pada taraf uji 5\% (uji selang berganda Duncan). 
Kandungan antosianin daun segar pada tanaman akar wangi ini rata-rata nilainya 0.26 $\mu$ mol $\mathrm{g}^{-1}$. Klorofil disintesis pada daun dan berperan untuk menangkap cahaya matahari yang jumlahnya berbeda-beda untuk setiap tanaman. Karoten berpigmen kuning sampai merah dengan rumus empiris $\mathrm{C}_{40} \mathrm{H}_{56}$ yang membantu menyerap spektrum cahaya matahari kemudian diteruskan ke klorofil a dan klorofil b karena energi eksitasi digunakan untuk proses fotosintesis, dimana klorofil a (juga disebut $\mathrm{A}_{0}$ ) merupakan penerima elektron utama yang tidak hanya berperan dalam pemanenan cahaya, pengubah energi cahaya menjadi energi kimia, dan bertindak sebagai penyumbang elektron utama (Govindjee dan Coleman, 1990).

\section{Biomassa yang Dihasilkan oleh Tanaman Vetiver}

Hasil analisis ragam (Tabel 5) menunjukkan bahwa biomassa yang dihasilkan tanaman akar wangi pada saat umur 48 MSP atau pada saat tanaman sudah bertepatan dengan waktu panen memiliki hasil yang banyak. Konsentrasi larutan hara tidak menunjukkan adanya pengaruh nyata terhadap biomassa bobot basah tajuk yang dihasilkan tanaman akar wangi baik pada Percobaan 1 dengan kondisi bahan tanam yang belum dilakukan pemotongan akar maupun pada Percobaan 2 dengan kondisi bahan tanam yang sudah dilakukan pemotongan akar. Bobot basah tajuk yang dihasilkan kemudian dilakukan pengeringan dengan menggunakan oven dengan suhu $80{ }^{\circ} \mathrm{C}$ di Laboratorium Pasca Panen IPB selama 24 jam, sehingga diperoleh biomassa bobot kering tajuk yang dapat dilihat pada Tabel 5.

Konsentrasi larutan hara menunjukkan adanya pengaruh nyata terhadap hasil biomassa bobot kering tajuk dalam Percobaan 1 maupun Percobaan 2. Konsentrasi larutan hara 400 ppm menunjukkan hasil biomassa bobot kering tajuk yang paling banyak dengan nilai biomassa bobot kering tajuk berturut-turut sebanyak 108.67 dan $73.50 \mathrm{~g}$.

Konsentrasi larutan hara $800 \mathrm{ppm}$ menghasilkan biomassa bobot kering tajuk berturut-turut sebanyak 82.67 dan $64.16 \mathrm{~g}$, sedangkan konsentrasi larutan hara 200 ppm memiliki hasil biomassa bobot kering tajuk yang paling sedikit dibandingkan dengan konsentrasi larutan hara yang lain dengan hasil biomassa bobot kering tajuk berturut-turut 60.33 dan 52.00 g pada Percobaan 1 dan Percobaan 2.

Tabel 5. Pengaruh konsentrasi larutan hara terhadap hasil biomassa tanaman vetiver pada umur 48 MSP

\begin{tabular}{|c|c|c|c|}
\hline Konsentrasi Larutan Hara & $\begin{array}{c}\text { Bobot Basah Tajuk } \\
(\mathrm{g})\end{array}$ & $\begin{array}{l}\text { Bobot Kering Tajuk } \\
(\mathrm{g})\end{array}$ & $\begin{array}{c}\text { Bobot Basah Akar } \\
(\mathrm{g})\end{array}$ \\
\hline \multicolumn{4}{|c|}{ Percobaan 1 (Tanpa Pemotongan Akar) } \\
\hline 200 ppm & 215.00 & $60.33 b$ & 207.00 \\
\hline $400 \mathrm{ppm}$ & 358.33 & $108.67 \mathrm{a}$ & 297.00 \\
\hline $800 \mathrm{ppm}$ & 287.33 & $82.67 \mathrm{ab}$ & 256.33 \\
\hline \multicolumn{4}{|c|}{ Percobaan 2 (Dengan Pemotongan Akar) } \\
\hline 200 ppm & 174.50 & $52.00 \mathrm{~b}$ & $26.00 \mathrm{~b}$ \\
\hline $400 \mathrm{ppm}$ & 217.83 & $73.50 \mathrm{a}$ & $33.33 \mathrm{a}$ \\
\hline $800 \mathrm{ppm}$ & 191.17 & $64.16 \mathrm{ab}$ & $30.58 \mathrm{a}$ \\
\hline
\end{tabular}

Keterangan: Angka-angka pada kolom yang sama yang diikuti oleh huruf yang sama tidak berbeda nyata pada taraf uji 5\% (uji selang berganda Duncan).

Konsentrasi larutan hara tidak menunjukkan adanya pengaruh nyata terhadap hasil biomassa bobot basah akar tanaman akar wangi pada Percobaan 1, tetapi konsentrasi larutan hara menunjukkan adanya pengaruh nyata terhadap hasil biomassa bobot basah akar pada Percobaan 2. Konsentrasi larutan hara $400 \mathrm{ppm}$ menghasilkan biomassa bobot akar paling banyak dengan nilai $33.33 \mathrm{~g}$, konsentrasi larutan hara 800 ppm menunjukkan hasil biomassa bobot basah akar dengan nilai $30.58 \mathrm{~g}$ dan konsentrasi larutan hara 200 ppm menunjukkan hasil biomassa bobot basah akar yang paling sedikit dibandingkan dengan konsentrasi larutan hara yang lain dengan nilai $26.00 \mathrm{~g}$ pada Percobaan 2. Akar wangi 
merupakan tanaman $\mathrm{C} 4$ yang sangat efisien dalam mengkonversi radiasi surya menjadi biomas (Vieritz et al., 2006), sehingga penambahan konsentrasi larutan hara dalam teknologi hidroponik sistem terapung yang sesuai akan mampu menyediakan unsur hara yang dibutuhkan bagi tanaman.

\section{KESIMPULAN}

Konsentrasi larutan hara meningkatkan pertumbuhan tinggi tanaman, jumlah anakan, jumlah anakan baru, bobot kering tajuk tanaman pada tanaman yang tidak dilakukan pemotongan akar (Percobaan 1), serta konsentrasi larutan hara meningkatkan jumlah anakan baru, dan bobot kering tajuk tanaman pada tanaman dengan pemotongan akar (Percobaan 2).

Perlakuan konsentrasi larutan hara 200 ppm menghasilkan pertumbuhan tanaman yang tercekam dan tidak berkembang dengan baik. Konsentrasi larutan hara yang menunjukkan hasil pertumbuhan tajuk dan perkembangan akar yang baik adalah konsentrasi larutan hara $400 \mathrm{ppm}$. Konsentrasi larutan hara 800 ppm juga menunjukkan hasil yang baik tetapi tidak sebaik konsentrasi larutan hara 400 ppm. Budi daya THST dapat diterapkan untuk budi daya tanaman akar wangi karena dapat menghasilkan pertumbuhan dan produksi tajuk serta perakaran yang baik.

\section{DAFTAR PUSTAKA}

Gomez, K.A., A.A. Gomez. 1995. Prosedur Statistika untuk Percobaan Pertanian. Sjamsudin, E. J.S. Baharsjah, penerjemah. UI Press. Terjemahan dari: Statistical Procedures for Agricultural Research. Jakarta.

Govindjee, W.J. Coleman.1990. How plants make oxygen. Scientific American 262(2): 50-58. America (US).

Hendriyani, I.S., N. Setiari. 2009. Kandungan klorofil dan pertumbuhan kacang panjang (Vigna sinensis) pada tingkat penyediaan air yang berbeda. J Sains \& Mat. 17(3): 145-150.

Kardinan, A. 2005. Tanaman Penghasil Minyak Atsiri. Agromedia. Tanggerang.

Mulyati, H, A. Setiawan, M. Rusli. 2009. Rancang Bangun Sistem Manajemen Rantai Pasokan dan Risiko Minyak Akar Wangi Berbasis I KM di Indonesia, Institut Pertanian Bogor. Bogor.

Mulyono, E., D. Sumangat, T. Hidayat. 2012. Peningkatan mutu dan efisiensi produksi minyak akar wangi melalui teknologi penyulingan dengan tekanan uap bertahap. Bul. Tek. Pascapanen Pertanian. 8(1): 35-47.

Ramadiani, F.L, A.D. Susila. 2014. Sumber dan frekuensi aplikasi larutan hara sebagai pengganti $\mathrm{AB}$ mix pada budidaya sayuran daun secara hidroponik. J. Hort. Indonesia. 5(1) : 36-46.

Resh, H.M. 1998. Hydroponic Food Production: A Definitive Guidebook of Soilless Food-Growing Methods $\left(6^{\text {th }}\right.$ Edition). New-concept Press, Inc. 567 p. New Jersey (US).

Rosihan, R., O. Trisilawati, Setiawan, Makmun, T. Santoso, Zainudin. 2010. Respon Nomor Harapan Akarwangi terhadap Pemupukan N, P dan $\mathrm{K}$. Laporan Teknis Penelitian Tahun Anggaran 2010 Balai Penelitian Tanaman Obat dan Aromatik. 11hal.

Rosman, R., O. Trisilawati, Setiawan. 2013. Pemupukan nitrogen, fosfor, dan kalium pada tanaman akar wangi. Jurnal Littri. 19(1): 33-40.

Sani. 2011. Minyak dari Tumbuhan Akar Wangi. Unesa University Pr. Surabaya.

Vieritz, A.P. Troung, T. Gardner, C. Smeal. 2006. Modelling monto vetiver and nutrient uptake for effluent irrigation schemes. Pp 87-99.

Susila, A.D. 2013. Sistem Hidroponik. IPB Pr. Bogor. 